\title{
Potensi Terapi Mesenchymal Stem Cells (MSCs) Untuk Gagal Hati Kronis Eksaserbasi Akut Akibat Infeksi Virus Hepatitis B: Tinjauan Sistematis dan Meta- analisis Terhadap Studi Uji Acak Terkontrol
}

\author{
Yehuda Tri Nugroho Supranoto ${ }^{1^{*}}$, Dini Cynthia Dewi Tanuwijaya ${ }^{1}$, Irawan \\ Fajar Kusuma ${ }^{1,2}$ \\ 1. Fakultas Kedokteran Universitas Jember, Indonesia \\ 2. Departemen Ilmu Penyakit Dalam RSD dr. Soebandi Jember, Indonesia
}

Korespondensi : yehuda.supranoto@gmail.com

\begin{abstract}
ABSTRAK
Pendahuluan: Gagal hati kronis eksaserbasi akut merupakan dekompensasi penyakit hati kronis yang sering berkaitan dengan infeksi virus hepatitis B (HBV). Terapi Mesenchymal stem cells (MSCs) telah menunjukkan hasil yang menjanjikan untuk meningkatkan fungsi hati secara in vivo. Kajian ini bertujuan untuk menilai potensi MSCs pada pasien dengan gagal hati kronis eksaserbasi akut terkait infeksi HBV.

Metode: Meta-analisis ini dibuat berdasarkan pedoman PRISMA. Pencarian literatur dilakukan dengan beberapa database elektronik, yakni PubMed, ScienceDirect, PMC, Google Scholar, dan Cochrane Library. Risk ratio (RR) dan standardized mean difference (SMD) dengan standar deviasi (SD) digunakan untuk membandingkan risiko mortalitas, skor model for end-stage liver disease (MELD), dan total bilirubin (TBIL) dari pemberian MSCs dan standard medical therapy (SMT).

Hasil: Kajian ini menunjukkan bahwa risiko mortalitas cenderung lebih tinggi pada kelompok SMT (pooled RR=0.52, 95\%CI $(0.40,0,69), \mathrm{p}<0.00001, I^{2}=0 \%$ ). Skor MELD juga cenderung lebih tinggi pada kelompok SMT sampai 12 bulan setelah pengobatan (pooled SMD 0.36, 95\%CI $\left.(0.07,0.65), \mathrm{p}=0.00002, I^{2}=65 \%\right)$. Perubahan TBIL lebih besar pada kelompok MSCs sampai dengan 4 minggu (pooled $\mathrm{SMD}=0.20,95 \% \mathrm{CI}(-$ $0.11,0.52), \mathrm{p}=0.3, I^{2}=16 \%$ ) dan perubahan TBIL secara keseluruhan sampai 12 bulan menunjukkan adanya perbedaan antara intervensi MSCs dan SMT (pooled SMD $=-0.07$, $95 \%$ CI $\left.(-0.23,0.08), \mathrm{p}=0.05, I^{2}=42 \%\right)$.

Kesimpulan: Kajian ini memberikan bukti kuat yang menunjukkan terapi MSCs memiliki potensi yang bermanfaat untuk meningkatkan fungsi hati pada pasien dengan gagal hati kronis eksaserbasi akut terkait infeksi HBV.
\end{abstract}

Kata Kunci: Gagal hati kronis eksaserbasi akut; Infeksi virus hepatitis B; MSCs; Tinjauan sistematis; Meta-analisis

\begin{abstract}
Introduction: Acute-on-chronic liver failure (ACLF) is decompensation of chronic liver disease that is frequently related to the infection of Hepatitis $B$ virus (HBV). Mesenchymal stem cells (MSCs) transfusion have already been shown a promising result to improve liver function in vivo. This review aimed to assess the potencies of MSCs for ACLF patients associated with HBV infection.

Methods: This meta-analysis was reported based on PRISMA guidelines. A literature search was conducted with multiple electronic databases, including PubMed, ScienceDirect, PMC, Google Scholar, and Cochrane Library. Risk ratio (RR) and standardized mean difference (SMD) with standard deviation $(S D)$ were used to compare the risk of mortality, model for end-stage liver disease (MELD) score, and total bilirubin (TBIL) outcomes of MSCs and Standard Medical Therapy (SMT) intervention.
\end{abstract}


Results: This review showed that risk of mortality tends to be higher in the SMT group (pooled RR=0.52, 95\%CI $\left.(0.40,0,69), p<0.00001, I^{2}=0 \%\right)$. The MELD score also strongly associated with the treatment and tends to be higher in the SMT group until 12 months after treatment (pooled SMD 0.36, 95\%CI (0.07, 0.65), $p=0.00002, I^{2}=65 \%$ ). The change of TBIL is bigger on MSCs intervention until 4 weeks (pooled $S M D=0.20,95 \% C I$ (-0.11,0.52), $\left.p=0.3, I^{2}=16 \%\right)$ and the overall change of TBIL until 12 months showed a differences between MSCs and SMT intervention (pooled SMD = -0.07, 95\%CI ($0.23,0.08), p=0.05, I^{2}=42 \%$ ).

Conclusion: This review provides strong evidence showing MSCs treatment has beneficial potencies to elevate the liver function in a patient with $H B V$-related ACLF.

Keywords: ACLF; HBV infection; MSCs; Systematic review; Meta-analysis

\section{PENDAHULUAN}

Infeksi virus Hepatitis B merupakan salah satu masalah kesehatan global utama. Diperkirakan 2 miliar orang di seluruh dunia telah terinfeksi oleh virus ini, dan 650.000 orang diantaranya meninggal setiap tahunnya akibat komplikasi dari Hepatitis B kronis, seperti sirosis, gagal hati, dan kanker hepatoselular. ${ }^{1}$ Selain itu, $75 \%$ pasien dengan Hepatitis B kronis di seluruh dunia berasal dari Asia Tenggara dan Pasifik Barat, yang menjadikannya sebagai salah satu masalah utama di Indonesia. ${ }^{2}$

Gagal hati kronis eksaserbasi akut, atau yang juga dikenal sebagai Flare Hepatitis $B$, didefinisikan sebagai suatu sindrom yang ditandai oleh dekompensasi akut penyakit hati kronis yang terkait dengan kegagalan organ dan mortalitas jangka pendek yang tinggi. ${ }^{3}$ Flare Hepatitis $B$ paling sering terjadi pada fase imunoaktif (40-50\%), dimana pada fase ini terjadi peningkatan aktivitas sel imun, kadar Serum Glutamic Pyruvate Transaminase (SGPT), dan kadar virus Hepatitis B. Hal ini juga dapat terjadi selama fase resolusi namun lebih jarang dibandingkan dengan fase imunoaktif. Manifestasi klinisnya bervariasi dari asimtomatis sampai menyerupai hepatitis akut berat dengan tandatanda dekompensasi hati (ikterik, asites, dan ensefalopati hepatik), bahkan dapat menyebabkan kematian. ${ }^{4}$

Rendahnya tingkat harapan hidup pasien dengan gagal hati kronis eksaserbasi akut yang dikarenakan adanya gagal organ multipel, membuat terapi transplantasi hati menjadi solusi tunggal dan terapi definitif yang ada saat ini. Transplantasi hati menunjukkan perbaikan hasil pada banyak kasus gagal hati kronis eksaserbasi akut. Namun, kurangnya ketersediaan donor membuat transplantasi hati sering dianggap sebagai kontraindikasi pada kasus dengan kualitas hidup setelah transplantasi yang rendah $(<50 \%$ dalam 5 tahun). Faktor pencetus juga menjadi salah satu kriteria apakah seseorang dengan gagal hati kronis eksaserbasi akut dapat dilakukan transplantasi. ${ }^{5}$ Selain itu, daftar tunggu yang panjang, biaya tinggi, dan komplikasi yang dapat terjadi (seperti penolakan, masalah yang terkait dengan penggunaan imunosupresan jangka panjang, dan morbiditas dan mortalitas perioperatif) seringkali menjadikan hal ini sebagai pilihan yang tidak praktis bagi banyak pasien. ${ }^{6}$

Terapi berbasis sel punca muncul sebagai alternatif baru untuk pengobatan penyakit hati stadium akhir. Mesenchymal stem cells (MSCs) merupakan sel multipoten yang memiliki kemampuan memperbaharui diri dan berpotensi untuk berdiferensiasi menjadi berbagai jenis sel, termasuk hepatosit. Lebih penting lagi, sel-sel ini dapat berinteraksi dengan sel-sel imun, yang mengarah ke imunomodulasi. ${ }^{7}$ Terapi MSCs pada gagal hati kronis memiliki potensi untuk menurunkan derajat keparahan dan meningkatkan prognosis baik yang dinilai dari 
beberapa keluaran hasil baik seperti penurunan skor Model for End-Stage Liver Disease (MELD), total bilirubin (Tbil), dan risiko mortalitas. Skor MELD merupakan sistem penilaian prognostik, berdasarkan parameter laboratorium yang digunakan untuk memprediksi kematian dalam 3 bulan akibat penyakit hati.

Untuk memperoleh bukti ilmiah kuat terkait potensi terapi MSCs terhadap pasien dengan gagal hati kronis eksaserbasi akut, sebuah tinjauan sistematis dan meta-analisis sangatlah perlu dilakukan secara berkala. Oleh karena itu, penelitian ini bertujuan untuk menilai secara sistematis potensi terapi MSCs dengan membandingkannya secara kualitatif dan kuantitatif serta sistematis pada terapi medis standard (Standard Medical Therapy/SMT) pada pasien dengan gagal hati kronis eksaserbasi akut yang disebabkan oleh infeksi virus hepatitis B.

\section{METODE}

\section{Metodologi Penelitian}

Penelitian ini mengikuti pedoman Preferred Reporting Items for Systematic Reviews and Meta-Analyses (PRISMA). Protokol penelitian meta-analisis ini telah diregistrasi dan dipublikasi di International Prospective Register of Systematic Reviews (PROSPERO) dengan nomor registrasi CRD42021266956.

\section{Kriteria Kelayakan}

Kriteria kelayakan studi yang digunakan untuk menentukan studi inklusi meliputi tipe studi penelitian, jenis sampel, ukuran hasil, tes indeks, dan standar referensi.

\section{Tipe Studi Penelitian.}

Studi penelitian asli atau laporan penelitian yang membandingkan terapi MSCs dan SMT pada pasien gagal hati kronis eksaserbasi akut akibat infeksi virus hepatitis B merupakan studi yang terinklusi. Tinjauan naratif, tinjauan sistematis, meta-analisis, penelitian non-komparatif, penelitian in vitro, laporan teknis penelitian, tanggapan editor, protokol penelitian, dan abstrak konferensi termasuk dalam studi yang tereksklusi. Studi yang tidak dapat diakses secara penuh, studi dengan Bahasa selain Inggris dan Indonesia, serta topik yang tidak relevan juga termasuk dalam studi yang tereksklusi.

Jenis Sampel.

Sampel yang digunakan dalam studi penelitian tersebut merupakan pasien dengan gagal hati kronis eksaserbasi akut akibat infeksi virus hepatitis B. Dalam penelitian tersebut, kelompok perlakuan merupakan pasien gagal hati kronis eksaserbasi akut akibat infeksi virus hepatitis B yang memperoleh terapi MSCs. Kelompok kontrol dalam penelitian tersebut merupakan pasien gagal hati kronis eksaserbasi akut akibat infeksi virus hepatitis B yang memperoleh SMT.

Ukuran Hasil.

Ukuran hasil yang dinilai pada penelitian tinjauan sistematis dan metaanalisis ini meliputi skor model for end-stage liver disease (MELD), nilai total bilirubin (Tbil), dan risiko mortalitas. Skor MELD memiliki rentang nilai 6 hingga 40 yang menunjukkan semakin tinggi nilainya, semakin tinggi potensi mortalitas pasien karena penyakit hati. Kerusakan hati juga ditandai dengan peningkatan total bilirubin, sehingga terapi MSCs diharapkan dapat menurunkan total bilirubin sebagai indikator perbaikan kondisi hati. Risiko mortalitas merupakan nilai rujukan akhir yang menjadikan indikator potensi terapi MSCs dibandingkan dengan SMT.

Tes Indeks

Studi penelitian yang mengevaluasi perubahan nilai skor MELD, Tbil, dan risiko mortalitas diinklusikan untuk dilakukan analisis secara kuantitatif. Sementara, studi penelitian yang tidak menyertakan perubahan nilai skor MELD, Tbil, dan risiko mortalitas, namun membahas terapi MSCs untuk gagal hati kronis eksaserbasi akut akibat infeksi 
Supranoto et al., Potensi Terapi Mesenchymal Stem Cells (MSCs) untuk Gagal Hati Kronis Eksaserbasi Akut Akibat Infeksi Virus Hepatitis B: Tinjauan Sistematis dan Meta-analisis terhadap Studi Uji Acak Terkontrol

virus hepatitis B tetap diinklusikan untuk dilakukan analisis secara kualitatif.

\section{$\underline{\text { Standar Referensi }}$}

Standar referensi studi penelitian yang digunakan merupakan studi penelitian asli atau orisinil dengan metode penelitian Randomized Controlled Trial (RCT) atau Uji Acak Terkontrol dengan mencantumkan nilai keluaran hasil perubahan nilai skor MELD, Tbil, dan risiko mortalitas pasien gagal hati kronis eksaserbasi akut setelah diberi terapi MSCs dan SMT.

\section{Sumber Data dan Strategi Pencarian Data}

Pencarian literatur dilakukan pada beberapa database yaitu MEDLINE (PubMed), PMC, Google Scholar, ScienceDirect, dan CENTRAL (Cochrane Library). Pencarian studi dilakukan hingga Maret 2021. Kata kunci yang digunakan untuk pencarian studi telah sesuai dengan pedoman Boolean operator. Seluruh studi yang ditemukan disimpan dalam aplikasi Rayyan.ai.

\section{Seleksi Studi}

Setelah studi duplikat disingkirkan, studi yang telah ditemukan dari seluruh database disaring berdasarkan judul dan abstrak oleh tiga penulis (YTNS, DCDT, dan IFK). Studi yang memiliki potensi kelayakan yang tinggi dinilai dan dievaluasi oleh penulis lebih lanjut. Perbedaan pendapat antara reviewer diselesaikan dengan konsensus di antara penulis. Seluruh proses seleksi studi ini dijelaskan lebih lanjut dengan skema PRISMA.

\section{Ekstraksi dan Analisis Data Kualitatif}

Studi penelitian yang telah diinklusikan ditinjau kembali untuk proses ekstraksi data. Data disimpan dalam Microsoft Excel 2016 (Microsoft Corporation, USA) dan Rayyan.ai. Data yang diekstrak dari setiap studi penelitian meliputi: penulis utama, tahun terbit, negara, desain penelitian, besar sampel, usia, tipe MSC, skor MELD, dosis MSC, administrasi MSC, dan Follow up serta kualitas studi yang dinilai dari proses analisis risiko bias. Seluruh tes statistik untuk prosedur meta-analisis dilakukan dengan aplikasi Review Manager (RevMan) v5.4 (Cochrane Colaboration, UK).

\section{Analisis Risiko Bias di Setiap Studi Individu}

Kualitas setiap studi penelitian yang terinklusi dalam tinjauan sistematis ini dinilai oleh 2 penulis (YTNS dan DCDT) sesuai dengan pedoman Cochrane Risk of Bias (RoB) Tool untuk studi uji acak terkontrol. Kami mengeksklusi studi penelitian dengan risiko bias yang tinggi atau kualitas studi yang sangat rendah demi menjaga kekokohan data yang ditampilkan dalam penelitian ini.

\section{Analisis Data Kuantitatif}

Perbedaan rerata tersandarisasi (Standardized Mean Difference/SMD) dan deviasi standar (Standard deviation/SD) dengan interval kepercayaan (Confidence Interval/CI) sebesar 95\% digunakan dalam penelitian meta-analisis ini. Untuk menilai ukuran efek meta-analisis, kami menggunakan 2 tipe analisis forest plot, yaitu Fixed-effect model (FEM) dan Random-effect model (REM) sesuai dengan nilai heterogenitas yang muncul. FEM digunakan jika studi yang terinklusi bersifat homogen (variabilitas rendah) yang diindikasikan oleh nilai $I^{2}$ lebih rendah dari $50 \%$ pada forest plot. REM digunakan jika studi yang terinklusi bersifat heterogen (variabilitas tinggi) yang diindikasikan oleh nilai $I^{2}$ lebih tinggi dari $50 \%$ pada forest plot.

\section{Analisis Risiko Bias di Seluruh Studi}

Risiko bias di seluruh studi terinklusi dapat dinilai dari funnel plot yang didapatkan dari aplikasi Review Manager (RevMan) v5.4. Simetrisitas bentuk dari funnel plot menjadi indikator ada tidaknya bias publikasi. Bentuk 
funnel plot yang tidak simetris mengindikasikan adanya potensi bias pada meta-analisis ini.

\section{HASIL}

\section{Seleksi Studi}

Pencarian studi yang kami lakukan menemukan 1.847 studi dari 5 database seperti yang dijelaskan pada Tabel 1 di bawah ini. Dari penelusuran manual, kami menemukan 18 studi yang cocok dengan topik kami. Empat puluh delapan duplikat dari database tersebut telah dihapus. Kemudian, penulis membaca judul dan abstrak dari 996 studi yang tersisa untuk penyaringan awal. Penulis mengecualikan studi yang tidak memenuhi kriteria kelayakan yang telah ditentukan. Teks lengkap diambil untuk 803 studi penelitian dan 633 studi penelitian dikeluarkan karena studi tersebut tidak menjelaskan dengan jelas efek MSCs pada pasien dengan gagal hati kronis eksaserbasi akut akibat infeksi virus hepatitis B. Teks lengkap ditelaah kembali untuk 170 studi penelitian dan 136 penelitian diekslusikan karena studi penelitian tersebut tidak menjelaskan dengan jelas hasil pemberian MSCs pada pasien gagal hati kronis eksaserbasi akut akibat infeksi virus hepatitis B. Sebanyak 10 studi diinklusikan ke dalam tinjauan sistematis kualitatif (tujuh studi dari pencarian melalui database dan tiga studi dari pencarian manual). Sebanyak 5 studi diinklusikan untuk analisis kuantitatif. Proses seleksi studi ini, kami sajikan dalam skema PRISMA pada Gambar 1 di bawah ini.

Tabel 1. Strategi Pencarian Studi

\begin{tabular}{llc}
\hline \multicolumn{1}{c}{ Database } & \multicolumn{1}{c}{ Kata Kunci } & Jumlah Studi \\
\hline PubMed & (((Mesenchymal stem cells[Text Word]) AND (Hepatitis B & 130 \\
& Virus-related Acute-on-Chronic Liver Failure[Text Word])) OR & \\
& (Hepatitis B Virus-related Cirrhosis[Text Word])) OR (Hepatitis & \\
& B Virus-related Liver Fibrosis[Text Word]) & \\
\hline PMC & ("Mesenchymal Stem Cells" OR "MSCs") AND ("Hepatitis B & 81 \\
& Virus-related Acute-on-Chronic Liver Failure" OR "Hepatitis B & \\
& Virus-related Cirrhosis" OR "Hepatitis B Virus-related Liver & \\
\hline Google & Fibrosis") & \\
Scholar & ("Mesenchymal Stem Cells" OR "MSCs") AND ("Hepatitis B & 224 \\
& Virus-related Acute-on-Chronic Liver Failure" OR "Hepatitis B & \\
& Virus-related Cirrhosis" OR "Hepatitis B Virus-related Liver & \\
\hline Science & Fibrosis") & \\
Direct & ("Mesenchymal Stem Cells" OR "MSCs") AND ("Hepatitis B & 1348 \\
& Virus-related Acute-on-Chronic Liver Failure" OR "Hepatitis B & \\
\hline Cochrane & Virus-related Cirrhosis" OR "Liver Fibrosis") \\
Library & (("Mesenchymal Stem Cell”) AND ("Hepatitis B Virus-related & 64 \\
& Acute-on-Chronic Liver Failure” OR "Hepatitis B Virus-related & \\
& Cirrhosis" OR "Hepatitis B Virus-related Liver Fibrosis”)) & \\
\hline
\end{tabular}


Supranoto et al., Potensi Terapi Mesenchymal Stem Cells (MSCs) untuk Gagal Hati Kronis Eksaserbasi Akut Akibat Infeksi Virus Hepatitis B: Tinjauan Sistematis dan Meta-analisis terhadap Studi Uji Acak Terkontrol

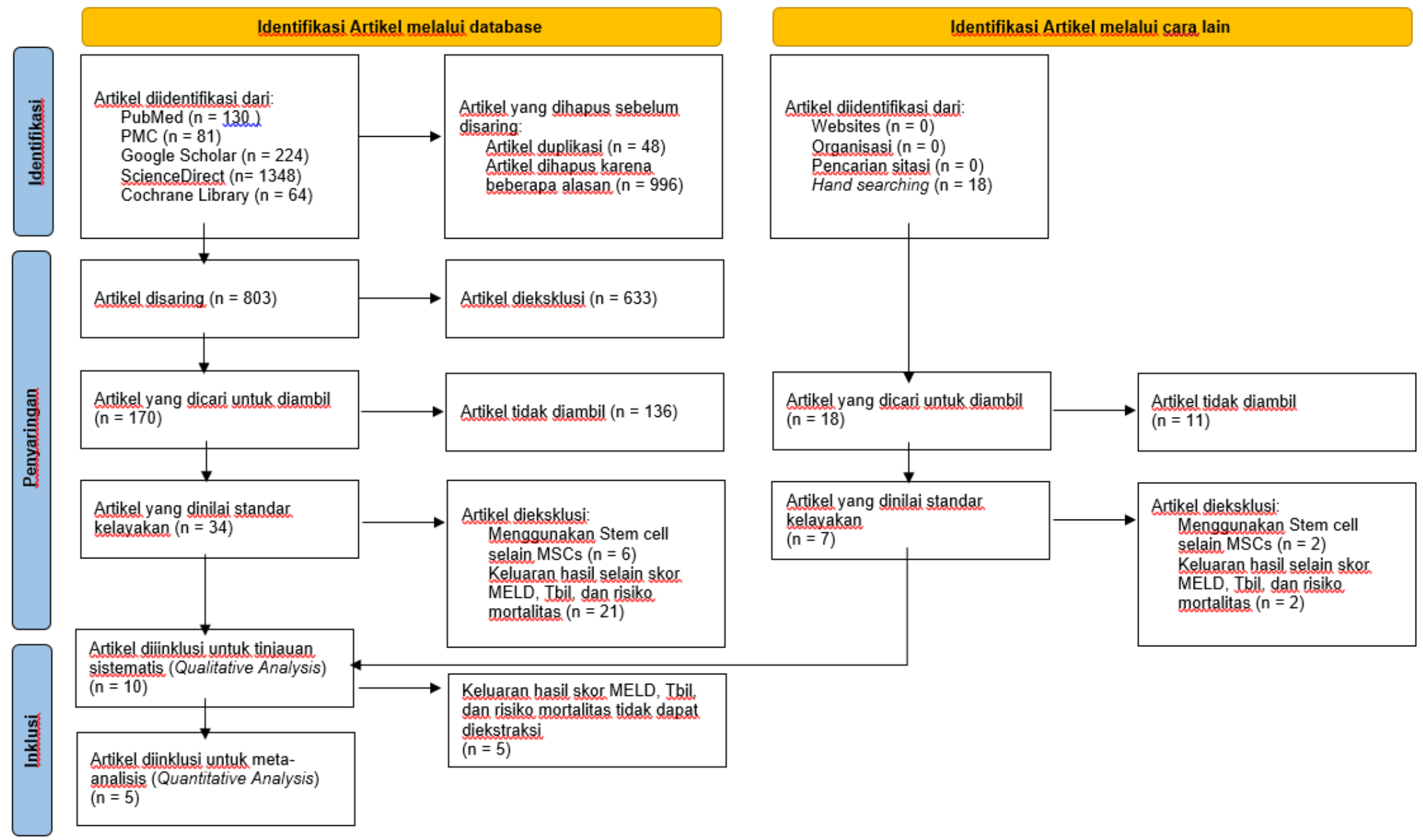

Gambar 1. Skema Pencarian Studi Sesuai Pedoman PRISMA 
Supranoto et al., Potensi Terapi Mesenchymal Stem Cells (MSCs) untuk Gagal Hati Kronis Eksaserbasi Akut Akibat Infeksi Virus Hepatitis B: Tinjauan Sistematis dan Meta-analisis terhadap Studi Uji Acak Terkontrol

Tabel 1. Karakteristik Studi Terinklusi

\begin{tabular}{|c|c|c|c|c|c|c|c|c|c|}
\hline Penulis Utama & Tahun & Negara & $\begin{array}{c}\text { Besar } \\
\text { Sampel }\end{array}$ & Usia & Tipe MSCs & Dosis MSCs & Follow Up & Administrasi & Kualitas Studi \\
\hline Jia et $a l^{8}$ & 2020 & China & 513 & $40(35-46,5) / 42(33-50)$ & UC-MSC & $1 \times 10^{6} \mathrm{sel} / \mathrm{kg}$ & 8 minggu & $\begin{array}{l}\text { Infus intravena/ } \\
\text { minggu selama } 4 \\
\text { minggu }\end{array}$ & Tinggi \\
\hline Li et $a l^{9}$ & 2016 & China & 51 & $51,1 \pm 11,2 / 50,0 \pm 10,9$ & UC-MSC & $100 \times 10^{6}$ sel $/ 60 \mathrm{~mL}$ saline & 24 bulan & Arteri hepatic 1 kali & Rendah \\
\hline Lin $e t a l^{10}$ & 2017 & China & 110 & $40 \pm 9,9 / 42,8 \pm 8,4$ & $\begin{array}{l}\text { ABM- } \\
\text { MSC }\end{array}$ & $1,0-10 \times 10^{6} \mathrm{sel} / \mathrm{kg}$ & 24 minggu & $\begin{array}{lcc}\text { Infus intravena } & 3 \\
\text { kali } & \text { selama } & 4 \\
\text { minggu } & & \\
\end{array}$ & Tinggi \\
\hline Mohamadnejad et al ${ }^{11}$ & 2013 & Iran & 27 & $43,1 \pm 17,6 / 34,6 \pm 13,8$ & BM-MSC & $100 \mathrm{~mL}$ MSC in saline & 12 bulan & $\begin{array}{l}\text { Infus intravena } 1 \\
\text { kali }\end{array}$ & Sedang \\
\hline Peng et $a l^{12}$ & 2011 & China & 53 & $42,2 \pm 10,8 / 42,2 \pm 11,4$ & BM-MSC & $\begin{array}{l}3,4-3,8 \times 10^{7} \mathrm{sel} / 10 \mathrm{~mL} \\
\text { saline }\end{array}$ & 48 minggu & Arteri hepatic 1 kali & Rendah \\
\hline Shi et $a l^{7}$ & 2012 & China & 43 & $40(24-59) / 45926-62)$ & UC-MSC & $0,5 \times 10^{6} \mathrm{sel} / \mathrm{kg}$ & 72 minggu & $\begin{array}{lcc}\text { Infus intravena } & 3 \\
\text { kali dalam } & 4 \\
\text { minggu } & & \\
\end{array}$ & Tinggi \\
\hline Shi et $a l^{13}$ & 2021 & China & 252 & $47(19-65) / 48(21-65)$ & UC-MSC & $0,5 \times 10^{6} \mathrm{sel} / \mathrm{kg}$ & 48 minggu & $\begin{array}{lcc}\text { Infus intravena } & 3 \\
\text { kali dalam } & 4 \\
\text { minggu } & & \\
\end{array}$ & Tinggi \\
\hline $\mathrm{Xu}$ et $a l^{14}$ & 2019 & China & 110 & $44,97 \pm 11,8 / 40,7 \pm 9,89$ & UC-MSC & $1,0 \times 10^{5} \mathrm{sel} / \mathrm{kg}$ & 90 hari & $\begin{array}{ll}\text { Infus } & \text { intravena/ } \\
\text { minggu } & \text { selama } 4 \\
\text { minggu } & \\
\end{array}$ & Tinggi \\
\hline Xue $e t a l^{15}$ & 2015 & China & 50 & $32-78$ & UC-MSC & $3 \times 10^{7} \mathrm{sel} / 15 \mathrm{~mL}$ saline & 24 minggu & Arteri hepatic 1 kali & Sedang \\
\hline Zhang et $a l^{16}$ & 2012 & China & 45 & $47(29-64) / 48(25-64)$ & UC-MSC & $0,5 \times 10^{6} \mathrm{sel} / \mathrm{kg}$ & 40 minggu & $\begin{array}{lcc}\text { Infus intravena } & 3 \\
\text { kali } & \text { selama } & 4 \\
\text { minggu } & & \\
\end{array}$ & Rendah \\
\hline
\end{tabular}

RCT, Randomized Controlled Trial; PC, Prospective Cohort; UC-MSC, Umbilical Cord Mesenchymal Stem Cell; ABM-MSC, Allogenic Bone Marrow-derived

Mesenchymal Stem Cell; BM-MSC, Bone Marrow Mesenchymal Stem Cell 


\section{Analisis Data Kualitatif}

Detail ekstraksi data setiap studi terinklusi ditampilkan pada Tabel 2. Subjek penelitian ini merupakan pasien dengan diagnosis gagal hati kronis eksaserbasi akut akibat infeksi virus hepatitis B yang menerima terapi MSCs. Kami berfokus pada perubahan skor MELD, Tbil, dan risiko mortalitas pasca terapi MSCs tersebut. Dari 10 studi yang terinklusi dalam analisis kualitatif, 5 studi tidak menunjukkan nilai skor MELD, Tbil, dan risiko mortalitas pasca terapi MSCs pada pasien gagal hati kornis eksaserbasi akut akibat infeksi virus hepatitis $B$.

\section{Analisis Data Kuantitatif}

Kami membandingkan ukuran efek gabungan dari terapi MSCs dan SMT terhadap pasien gagal hati kronis eksaserbasi akut akibat infeksi virus hepatitis B berdasarkan perubahan nilai skor MELD (Gambar 2), Tbil (Gambar 3), dan risiko mortalitas (Gambar 4). Kami menggunakan nilai skor MELD dan Tbil dari evaluasi minggu ke-2, minggu ke-4, bulan ke-3, bulan ke-6, dan bulan ke-12. Sementara, terkait risiko mortalitas, kami menggunakan evaluasi pada bulan ke-12 dan evaluasi akhir pada setiap studi penelitian yang terinklusi.

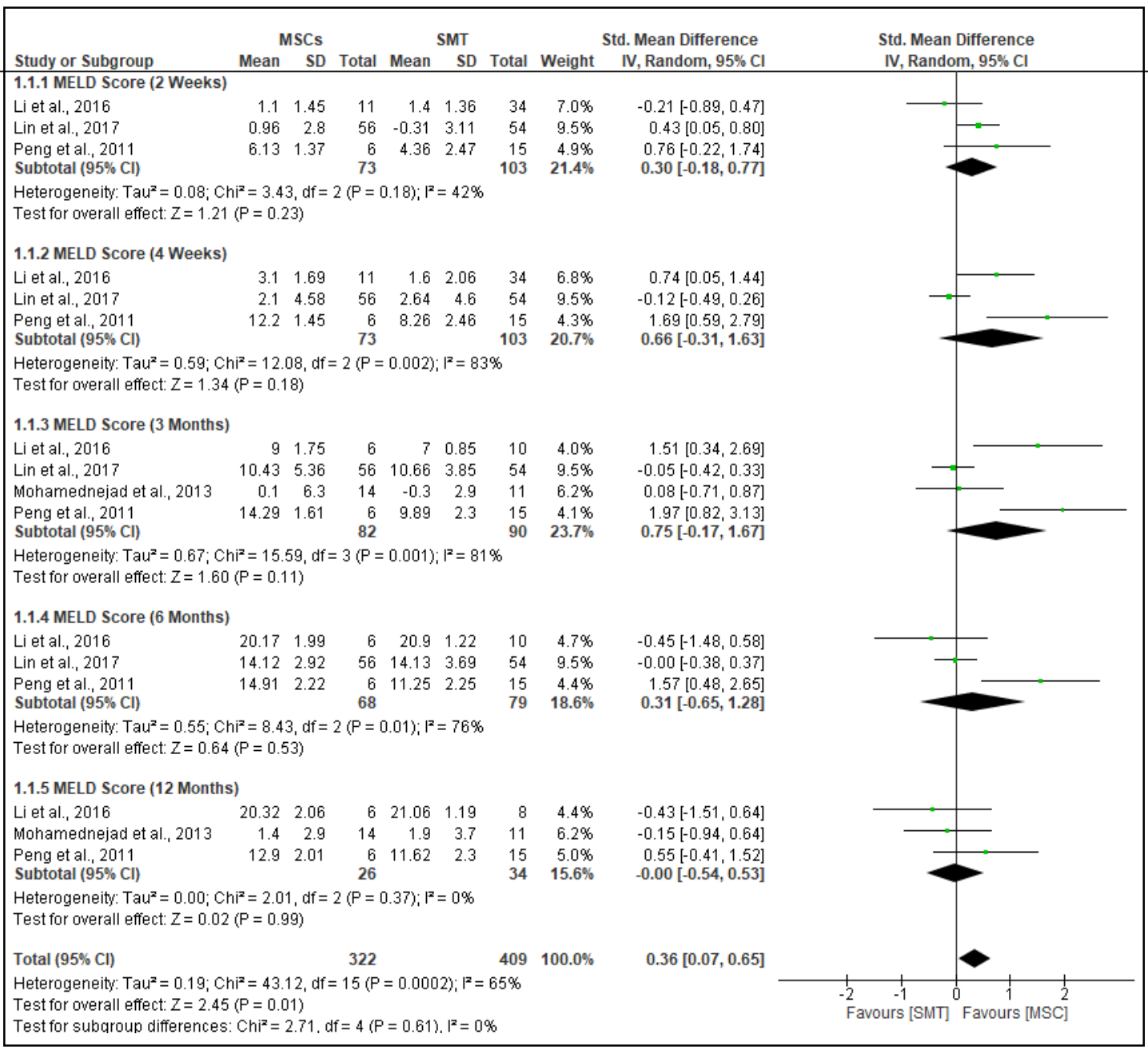

Gambar 2. Meta-analisis rata-rata perubahan skor MELD dari awal hingga setelah pemberian terapi MSCs dan SMT 
Supranoto et al., Potensi Terapi Mesenchymal Stem Cells (MSCs) untuk Gagal Hati Kronis Eksaserbasi Akut Akibat Infeksi Virus Hepatitis B: Tinjauan Sistematis dan Meta-analisis terhadap Studi Uji Acak Terkontrol

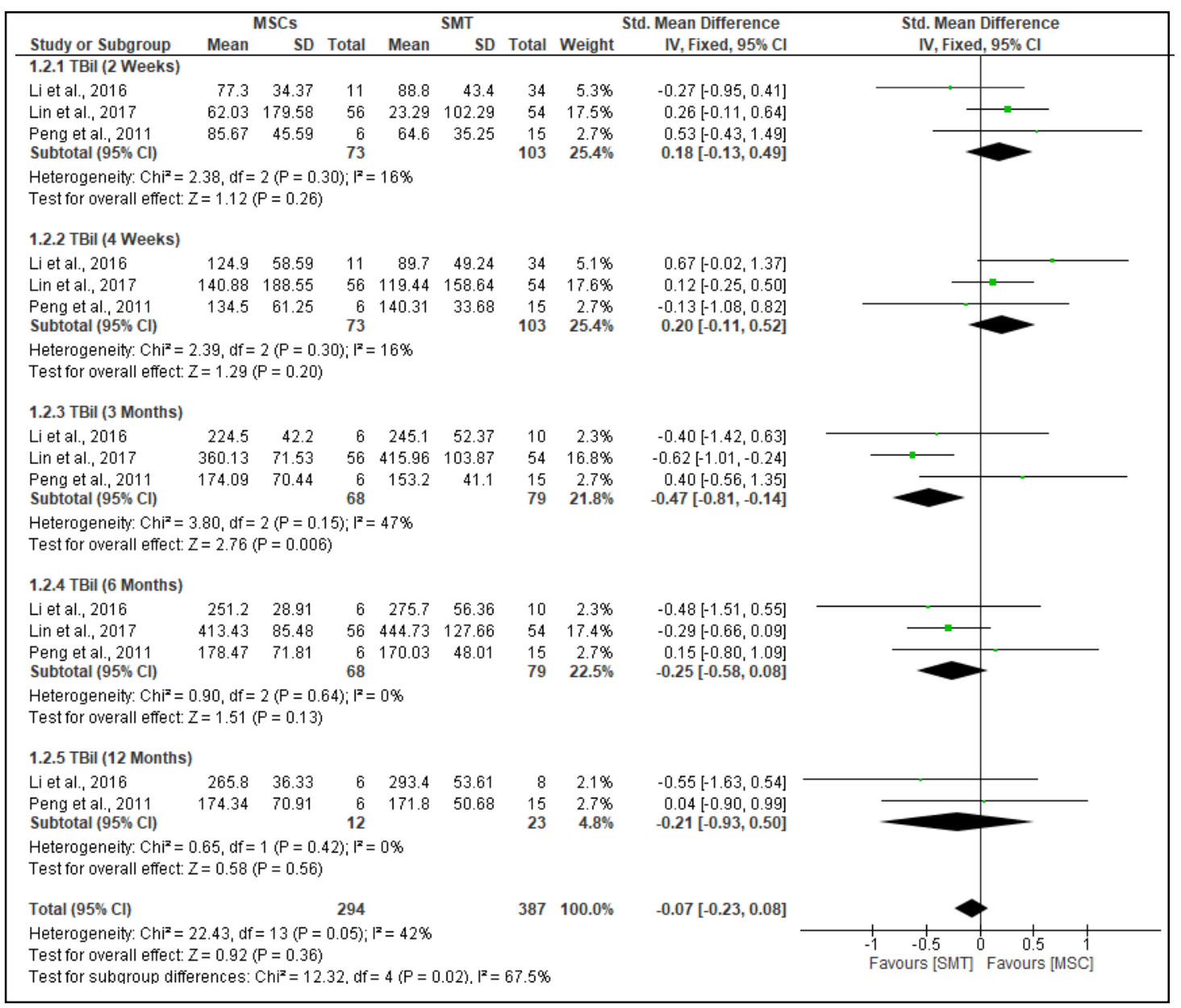

Gambar 3. Meta-analisis rata-rata perubahan nilai Tbil dari awal hingga setelah pemberian terapi MSCs dan SMT

\begin{tabular}{|c|c|c|c|c|c|c|c|c|c|c|}
\hline \multirow[b]{2}{*}{ Study or Subgroup } & \multicolumn{2}{|c|}{ MSC } & \multicolumn{2}{|c|}{ SMT } & \multirow[b]{2}{*}{ Weight } & \multirow{2}{*}{$\begin{array}{c}\text { Risk Ratio } \\
\text { M-H, Fixed, } 95 \% \mathrm{Cl}\end{array}$} & \multirow{2}{*}{\multicolumn{3}{|c|}{$\begin{array}{c}\text { Risk Ratio } \\
\text { M-H, Fixed, } 95 \% \mathrm{Cl} \\
\end{array}$}} & \\
\hline & Events & Total & Events & Total & & & & & & \\
\hline \multicolumn{10}{|c|}{ 2.1.1 Risk of Mortality at Week 12} & \\
\hline Li et al., 2016 & 5 & 11 & 24 & 34 & $12.4 \%$ & $0.64[0.33,1.27]$ & & & & \\
\hline Lin et al., 2017 & 11 & 56 & 21 & 54 & $22.5 \%$ & $0.51[0.27,0.95]$ & & & & \\
\hline $\begin{array}{l}\text { Shi et al., } 2012 \\
\text { Subtotal }(95 \% \mathrm{Cl})\end{array}$ & 5 & $\begin{array}{l}24 \\
91\end{array}$ & 11 & $\begin{array}{r}19 \\
107\end{array}$ & $\begin{array}{l}12.9 \% \\
47.9 \%\end{array}$ & $\begin{array}{l}0.36[0.15,0.86] \\
0.50[0.33,0.76]\end{array}$ & & & & \\
\hline \multicolumn{11}{|c|}{$\begin{array}{l}\text { Heterogeneity: } \mathrm{Chi}^{2}=1.08, \mathrm{df}=2(P=0.58) ; I^{2}=0 \% \\
\text { Test for overall effect: } Z=3.31(P=0.0009)\end{array}$} \\
\hline \multicolumn{11}{|c|}{ 2.1.2 Risk of Mortality at Final Follow Up } \\
\hline Li et al., 2016 & 5 & 11 & 26 & 34 & $13.4 \%$ & $0.59[0.30,1.17]$ & & & & \\
\hline Lin et al., 2017 & 15 & 56 & 24 & 54 & $25.8 \%$ & $0.60[0.36,1.02]$ & & & & \\
\hline $\begin{array}{l}\text { Shi et al., } 2012 \\
\text { Subtotal }(95 \% \mathrm{Cl})\end{array}$ & 5 & $\begin{array}{l}24 \\
91\end{array}$ & 11 & $\begin{array}{r}19 \\
107\end{array}$ & $\begin{array}{l}12.9 \% \\
52.1 \%\end{array}$ & $\begin{array}{l}0.36[0.15,0.86] \\
0.54[0.37,0.78]\end{array}$ & & & & \\
\hline \multicolumn{11}{|c|}{$\begin{array}{l}\text { Heterogeneity: } \mathrm{Chi}^{2}=1.08, \mathrm{df}=2(\mathrm{P}=0.58) ;\left.\right|^{2}=0 \% \\
\text { Test for overall effect: } Z=3.23(P=0.001)\end{array}$} \\
\hline Total $(95 \% \mathrm{Cl})$ & & 182 & & 214 & $100.0 \%$ & $0.52[0.40,0.69]$ & & & & \\
\hline Total events & 46 & & 117 & & & & & & & \\
\hline $\begin{array}{l}\text { Heterogeneity: } \mathrm{Chi}^{2}= \\
\text { Test for overall effect } \\
\text { Test for subqroup di }\end{array}$ & $\begin{array}{l}2.21, \mathrm{df}= \\
Z=4.62( \\
\text { erences: }\end{array}$ & $\begin{array}{l}5(\mathrm{P}= \\
\mathrm{P}<0.0 \\
\mathrm{Chi}^{2}=\end{array}$ & $\begin{array}{l}0.82) ; 1^{2}= \\
00001) \\
0.07 . \mathrm{df}=\end{array}$ & $\begin{array}{l}=0 \% \\
1(\mathrm{P}=\end{array}$ & $0.79) \cdot 1^{2}=$ & & 0.2 & $\begin{array}{c}1 \\
0.5 \\
\text { Favours [MSC] }\end{array}$ & \begin{tabular}{|c}
1 \\
2 \\
Favours [SMT]
\end{tabular} & 5 \\
\hline
\end{tabular}

Gambar 4. Meta-analisis risiko mortalitas pada minggu ke-12 dan pada akhir evaluasi setelah pemberian terapi MSCs dan SMT 
Hasil meta-analisis dengan random effect model rata-rata perubahan skor MELD dari awal hingga setelah pemberian terapi MSCs dan SMT pada pasien gagal hati kronis eksaserbasi akut akibat infeksi virus hepatitis B menunjukkan skor MELD cenderung lebih tinggi pada kelompok SMT sampai 12 bulan setelah pengobatan (pooled SMD 0.36, 95\% CI $\left.(0.07,0.65), \mathrm{p}=0.00002, I^{2}=65 \%\right)$. Hasil meta-analisis dengan fixed effect model ratarata perubahan nilai Tbil dari awal hingga setelah pemberian terapi MSCs dan SMT menunjukkan bahwa perubahan TBIL lebih besar pada kelompok MSCs sampai dengan 4 minggu (pooled $\mathrm{SMD}=0.20$, 95\% CI $\quad(-$ $\left.0.11,0.52), \mathrm{p}=0.3, I^{2}=16 \%\right)$ dan perubahan TBIL secara keseluruhan sampai 12 bulan menunjukkan adanya perbedaan antara intervensi MSCs dan SMT (pooled SMD= $\left.0.07,95 \% \mathrm{CI}(-0.23,0.08), \mathrm{p}=0.05, I^{2}=42 \%\right)$. Sementara itu, hasil meta-analisis dengan fixed effect model risiko mortalitas pada minggu ke-12 dan pada akhir evaluasi setelah pemberian terapi MSCs dan SMT menunjukkan bahwa risiko mortalitas cenderung lebih tinggi pada kelompok SMT (pooled $\mathrm{RR}=0.52, \quad 95 \% \mathrm{CI} \quad(0.40,0,69)$, $\left.\mathrm{p}<0.00001, I^{2}=0 \%\right)$.

\section{Analisis Risiko Bias di Seluruh Studi}

Untuk menilai tingkat bias publikasi, kami membuat funnel plot. Hasil analisis bias ini tidak menunjukkan tingkat bias yang terdeteksi tinggi yang dinilai dari simetrisitas grafik funnel plot. Analisis funnel plot ditampilkan pada Gambar 5 sebagai berikut.

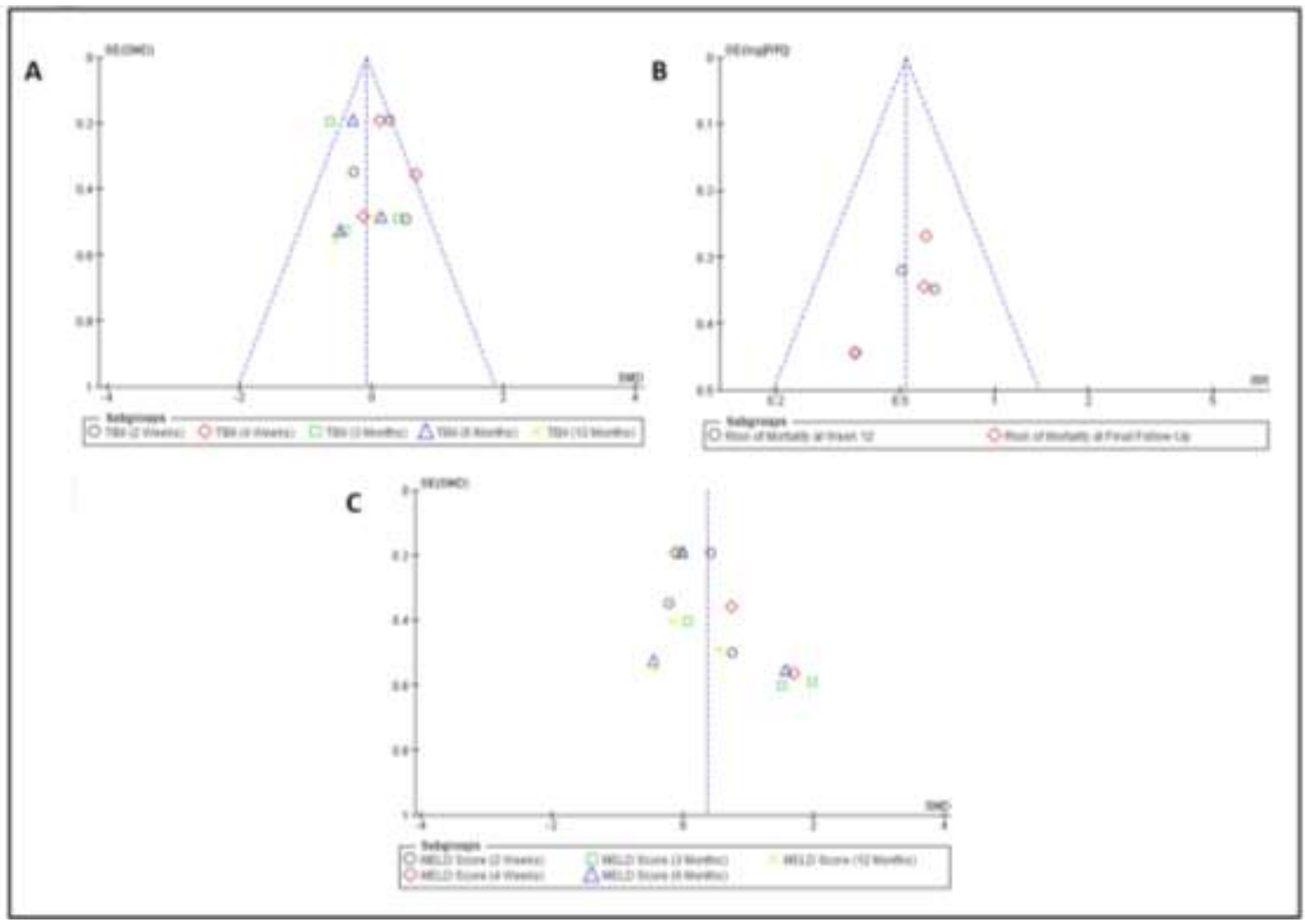

Gambar 5. Funnel Plot hasil meta-analisis. (A) Funnel Plot meta-analisis nilai Tbil dari evaluasi minggu ke-2, minggu ke-4, bulan ke-3, bulan ke-6, dan bulan ke-12. (B) Funnel Plot meta-analisis risiko mortalitas dari evaluasi minggu ke-12 dan evaluasi akhir. (C) Funnel Plot meta-analisis skor MELD dari evaluasi minggu ke-2, minggu ke-4, bulan ke-3, bulan ke-6, dan bulan ke12. 


\section{PEMBAHASAN}

Gagal hati kronis eksaserbasi akut ditandai dengan eksaserbasi akut pada pasien dengan penyakit hati kronis yang sudah ada sebelumnya, dengan reaktivasi infeksi HBV sebagai etiologi utamanya di Asia. Belum adanya terapi efektif yang tersedia selain transplantasi hati membuat penyakit ini memiliki prognosis yang buruk dengan angka mortalitas yang tinggi. ${ }^{9}$

Terapi berbasis sel punca muncul sebagai alternatif baru untuk pengobatan penyakit hati stadium akhir. Penelitian terbaru melaporkan bahwa pemberian UC-MSC secara signifikan meningkatkan tingkat kelangsungan hidup pada pasien Hepatitis B kronis yang mengalami gagal hati kronis eksaserbasi akut; mengurangi skor MELD; peningkatan serum albumin, kolinesterase, dan PTA; peningkatan jumlah PLT; dan penurunan kadar serum TBIL dan ALT. Hal ini terjadi karena UC-MSC memiliki kemampuan untuk berproliferasi dan berdiferensiasi menjadi beberapa jenis sel, salah satunya hepatosit. ${ }^{9}$

Penjelasan lain yang mungkin adalah karena UC-MSC secara umum meningkatkan fungsi hepatosit. Beberapa laporan sebelumnya menunjukkan bahwa MSC memiliki kapasitas untuk melakukan sekresi berbagai molekul bioaktif, seperti beberapa faktor pertumbuhan dan sitokin. Efek tersebut juga dapat meningkatkan proliferasi sel endogen dan revaskularisasi hati, seperti yang ditunjukkan pada hewan coba. Kontribusi efek parakrin lebih lanjut didukung oleh beberapa penelitian di mana pemberian MSC dapat menginduksi emigrasi selektif leukosit dari hati yang mengalami kerusakan, sehingga memodulasi respon imun terhadap cedera hati. $^{7}$

Selain itu, beberapa penelitian juga menemukan bahwa UC-MSC tidak mengekspresikan protein membran kompleks histokompatibilitas utama kelas II (MHC-II) dan hanya mengekspresikan MHC-I tingkat rendah, yang menunjukkan bahwa UC-MSC dapat lolos dari identifikasi sistem imun, sehingga tidak ada penolakan ketika UC-MSC diinjeksikan ke dalam tubuh. Oleh karena itu, pencocokan antigen leukosit manusia (HLA) tidak diperlukan dalam pemberian UC-MSC. ${ }^{15}$

Penelitian tinjauan sistematis dan meta-analisis ini bertujuan untuk mengevaluasi efektivitas dan keamanan dari terapi MSCs pada pasien gagal hati kronis eksaserbasi akut akibat infeksi virus hepatitis B. Hasil penelitian ini memberikan gambaran bahwa terapi MSC dapat menurunkan risiko mortalitas secara signifikan tanpa meningkatkan insidensi komplikasi serius, walaupun perlu ada penelitian lebih lanjut terkait peningkatan fungsi liver yang diambil dari indikator lain. Sebagai terapi baru, MSCs sangat dipertimbangkan oleh dokter dan pasien terkait tingkat keamanannya. Dari keseluruhan studi terinklusi, tidak ada efek samping berbahaya yang ditunjukkan dari pasien yang menjalani terapi dengan MSC dibanding pasien yang menjalani terapi dengan SMT. Hal ini menunjukkan bahwa penelitian ini dapat digunakan sebagai dasar ilmiah bahwa terapi MSC aman pada pasien gagal hati kronis eksaserbasi akut akibat infeksi virus hepatitis B. Berdasarkan hasil ukuran efek gabungan risiko mortalitas penelitian ini, terapi MSC sangat berdampak baik, dilihat dari signifikansi yang kuat serta homogenitas data dari keseluruhan studi terinklusi (pooled $\mathrm{RR}=0.52, \quad 95 \% \mathrm{CI}$ $\left.(0.40,0,69), \mathrm{p}<0.00001, I^{2}=0 \%\right)$.

Ketidakseimbangan imunitas dan inflamasi sistemik berperan penting dalam perkembangan gagal hati. Hasil penelitian yang dikemukakan Lin et al menunjukkan bahwa terapi MSCs meningkatkan fungsi imunomodulasi dan anti-inflamasi yang dapat 
meringankan peradangan hati, meningkatkan fungsi hati, mengurangi kejadian infeksi parah, dan meningkatkan tingkat kelangsungan hidup. $^{10}$ Penelitian yang dilakukan Shi et al juga menunjukkan bahwa tingkat $\alpha$-fetoprotein meningkat pada minggu ke-1 setelah terapi UC-MSC pertama, dan tetap pada level yang tinggi selama 8 minggu berikutnya. Selain itu, Shi et al juga menjelaskan bahwa level serum Tbil secara signifikan menurun setelah pemberian terapi UC-MSC. Namun, pada penelitian ini tidak didapatkan perbedaan penurunan level serum Tbil yang signifikan antara kelompok pemberian MSCs dan SMT (pooled SMD= $0.20,95 \%$ CI $\left.(-0.11,0.52), \mathrm{p}=0.3, I^{2}=16 \%\right)$. Hal ini berarti pemberian UC-MSC dapat meningkatkan proliferasi hepatosit dan membantu pasien pulih dari kondisi gagal hati kronis eksaserbasi akut akibat infeksi virus hepatitis B selama 3 bulan pertama. ${ }^{7}$

Skor MELD seringkali digunakan dalam menilai atau mengevaluasi prognosis dari penyakit hati stadium akhir. Kami menilai bahwa skor MELD menurun pada kelompok pemberian terapi MSCs dan SMT. Perbedaan yang signifikan telah ditunjukkan pada Gambar $2(\mathrm{p}=0,01)$. Walaupun terdapat perbedaan yang signifikan, hasil penelitian ini memiliki heterogenitas data $\left(I^{2}=65 \%\right)$. Hasil ini juga menunjukkan bahwa terapi MSCs dapat lebih menurunkan skor MELD pada pasien gagal hati kronis eksaserbasi akut akibat infeksi virus hepatitis B.

\section{KESIMPULAN}

Penelitian tinjauan sistematis dan meta-analisis ini menunjukkan bukti ilmiah bahwa terapi MSCs secara signifikan lebih menurunkan risiko mortalitas pasien dengan gagal hati kronis eksaserbasi akut akibat infeksi virus hepatitis B dibandingkan dengan terapi SMT. Penelitian ini juga menunjukkan terapi MSCs tidak menimbulkan efek samping yang berbahaya. Secara keseluruhan, terapi
MSCs efektif dan aman digunakan sebagai pilihan terapi pasien dengan gagal hati kronis eksaserbasi akut akibat infeksi virus hepatitis B.

\section{DAFTAR PUSTAKA}

1. Maulidia VNR, Wardhani P, Setyoboedi B. AST, ALT and Albumin Level in Chronic Hepatitis B Patients with and without Complications of Cirrhosis and Hepatocellular Carcinoma. Indones J Clin Pathol Med Lab. 2020;26(3):344-9.

2. Leroi C, Adam P, Khamduang W, Kawilapat S, Ngo-Giang-Huong N, Ongwandee S, et al. Prevalence of chronic hepatitis B virus infection in Thailand: a systematic review and meta-analysis. Int $\mathrm{J}$ Infect Dis [Internet]. 2016;51:36-43. Available from: http://dx.doi.org/10.1016/j.ijid.2016.08.017

3. Hernaez R, Solà E, Moreau R, Ginès P. Acute-on-chronic liver failure: An update. Gut. 2017;66(3):541-53.

4. Cahyono SB, Rasari N, Bayupurnama P, Maduseno S, Nurdjanah S. Reactivation and Flare of Chronic Hepatitis B: Natural History, Diagnosis, Therapy and Prevention. Acta Interna J Intern Med. 2014;4(1):40-9.

5. Trebicka J, Sundaram V, Moreau R, Jalan $\mathrm{R}$, Arroyo V. Liver Transplantation for Acute-on-Chronic Liver Failure: Science or Fiction? Liver Transplant. 2020;26(7):90615.

6. Kang SH, Kim MY, Eom YW, Baik SK. Mesenchymal stem cells for the treatment of liver disease: Present and perspectives. Gut Liver. 2020;14(3):306-15.

7. Shi M, Zhang Z, Xu R, Lin H, Fu J, Zou Z, et al. Human Mesenchymal Stem Cell Transfusion Is Safe and Improves Liver Function in Acute-on-Chronic Liver Failure Patients. Stem Cells Transl Med. 2012;1(10):725-31.

8. Jia Y, Shu X, Yang X, Sun H, Cao H, Cao $\mathrm{H}$, et al. Enhanced therapeutic effects of umbilical cord mesenchymal stem cells after prolonged treatment for HBV-related liver failure and liver cirrhosis. Stem Cell Res Ther. 2020;11(1):1-10.

9. Li YH, Xu Y, Wu HM, Yang J, Yang LH, Yue-Meng W. Umbilical Cord-Derived Mesenchymal Stem Cell Transplantation in Hepatitis B Virus Related Acute-onChronic Liver Failure Treated with Plasma Exchange and Entecavir: a 24-Month 
Prospective Study. Stem Cell Rev Reports [Internet]. 2016;12(6):645-53. Available from: http://dx.doi.org/10.1007/s12015016-9683-3

10. Lin BL, Chen JF, Qiu WH, Wang KW, Xie DY, Chen XY, et al. Allogeneic bone marrow-derived mesenchymal stromal cells for hepatitis B virus related acute-onchronic liver failure: a randomized controlled trial. Hepatology 2017; 66:209219.

11. Mohamadnejad M, Alimoghaddam K, Bagheri M, Ashrafi M, Abdollahzadeh L, Akhlaghpoor S, et al. Randomized placebocontrolled trial of mesenchymal stem cell transplantation in decompensated cirrhosis. Liver Int. 2013;33(10):1490-6.

12. Peng L, Xie D ying, Lin BL, Liu J, Zhu H peng, Xie C, et al. Autologous bone marrow mesenchymal stem cell transplantation in liver failure patients caused by hepatitis B: Short-term and long-term outcomes. Hepatology. 2011;54(3):820-8.

13. Shi M, Li Y, Xu R, Meng F, Yu S, Fu J, et al. Mesenchymal Stem Cell Therapy in Decompensated Liver Cirrhosis: A LongTerm Follow-up Analysis of the Randomized Controlled Clinical Trial. :114.

14. $\mathrm{Xu} \mathrm{W}$ xiong, He $\mathrm{H}$ liang, Pan $\mathrm{S}$ wen, Chen $\mathrm{Y}$ li, Zhang $\mathrm{M}$ ling, Zhu $\mathrm{S}$, et al. Combination treatments of plasma exchange and umbilical cord-derived mesenchymal stem cell transplantation for patients with hepatitis B virus-related acuteon-chronic liver failure: A clinical trial in China. Stem Cells Int. 2019;2019.

15. Xue HL, Zeng WZ, Wu XL, Jiang MD, Zheng SM, Zhang Y, et al. Clinical therapeutic effects of human umbilical cordderived mesenchymal stem cells transplantation in the treatment of end-stage liver disease. Transplant Proc. 2015;47(2):412-8.

16. Zhang Z, Lin H, Shi M, Xu R, Fu J, Lv J, et al. Human umbilical cord mesenchymal stem cells improve liver function and ascites in decompensated liver cirrhosis patients. J Gastroenterol Hepatol. 2012;27(SUPPL.2):112-20. 